\title{
FINANCING OUR FOREIGN TRADE
}

\author{
By Frederick I. Kent, \\ Vice-President, Bankers Trust Company, New York.
}

The foreign trade of the United States has increased during the last forty years about 370 per cent. The combined exports and imports in 1870 were exceeded by the exports alone in 1880 , and in 1909 the total foreign trade was almost double that of 1880 and amounted last year to $\$ 3,203,000,000$. This increase in our foreign trade reflected not alone our own marvelous development, but as well the wonderful growth of trade throughout the world. The United States stands third among the countries of the world, its foreign trade being exceeded only by that of the United Kingdom of Great Britain, whose total in 1909 reached $\$ 4,88 \mathrm{I}, 000,000$, and Germany with a total of $\$ 3,544,000,000$; France was fourth with $\$ \mathrm{I}, 995,000,000$.

Before considering the methods under which our trade is financed, it would be well to have in mind the nature of our foreign trade, including in a general way the commodities imported and exported and the points from which they emanate and to which they go.

Imports each exceeding $\$ 100,000,000$ in value:

Beverages, including coffee, tea and cocoa.

Silk and manufactures.

Hides, skins and leather.

Metals-copper, iron, tin and lead.

Under $\$ 100,000,000$ and exceeding $\$ 75,000,000$ :

Sugar.

Various chemicals.

India rubber.

Wool and manufactures.

Under $\$ 75,000,000$ and exceeding $\$ 50,000,000$ :

Manufactures of cloth and laces.

Fruits and nuts.

Wood and manufactures.

(492) 
Under $\$ 50,000,000$ and exceeding $\$ 20,000,000$ :

Wines and spirits.

Diamonds and precious stones.

Tobacco.

Furs.

These few commodities represented about seventy-seven per cent of our imports in the year I909. Of the total imports $\$ 763$,ooo,000 came from Europe, $\$ 277,000,000$ from North America, \$193,000,000 from South America, \$190,000,000 from Asia, \$32,000,000 from Oceanica, $\$ 17,000,000$ from Africa. Aside from the imports from North America, practically all of these commodities were financed through Europe and a large proportion of this total through London. The detail of this financing was largely carried on under the instrument known as the commercial letter of credit. An explanation of the operation of the commercial letter of credit will, therefore, disclose the methods and conditions under which our imports are financed.

The commercial letter of credit is an authorization, say of an American bank to its London correspondent, to honor drafts for its account drawn at various tenors by foreign shippers or others against shipments of merchandise to this country. These credits are of two kinds, documentary and clean. Under the documentary credit the London bank is authorized to accept drafts for the account of the American bank only when the bill of exchange is accompanied by certain documents described in the letter of credit. These documents may be the bills of lading for the goods, consular invoices, insurance certificates and possibly other papers. Probably a large proportion of such credits requires that drafts be drawn at sixty or ninety days' sight. So many elements of danger are involved in financing commodities under commercial letters of credit, even where the control of the goods is given to the bank issuing the credit or its agents, that the financial standing of those asking for credits must be the first consideration in their issuance. Dishonesty on the part of the shipper, resulting in a drawing under the credit against forged documents or against shipments of inferior merchandise, is always possible, and the financial responsibility of the buyer of the credit is all that stands between the banker issuing the credit and a loss in such cases.

In order to obtain a clear understanding of the working of a (493) 
commercial letter of credit, we will take a concrete example and follow its every transaction. An importer of coffee (A) in New York purchases a certain number of bags of coffee from an exporter (B) in Brazil. A agrees to furnish B with a commercial letter of credit. $B$ is not in position, we will say, to await the arrival of the coffee in New York and the return of a remittance before receiving his pay. $A$ on the other hand is unable to remit $B$ for the coffee before its receipt and sale to his customers. A goes to his banker in New York and requests him to authorize B to draw upon the New York banker's London correspondent at ninety days' sight with bills of lading for coffee to the amount of the purchase attached to the draft, consular invoice and insurance certificate, if $B$ is to furnish the insurance. If A's banker is willing to extend the credit he writes a letter (or uses a printed form), requesting his London banker to accept B's drafts upon presentation under the conditions already mentioned and others of minor importance. This letter is issued in duplicate, one copy going to the London banker, the other being delivered to $A$. A then mails the copy received by him to $B$. B thereupon arranges to ship the coffee, obtains the bill of lading, invoice, etc., and takes them with the copy of the credit to his banker in Brazil. A draft is then drawn on the London bank under the terms of the credit at ninety days' sight and is discounted by the Brazilian banker, the proceeds being placed to the credit of B's account or given to him in the form of a check or cash. The Brazilian banker then forwards the draft and documents, except such documents as the instructions may require to be forwarded direct to New York, to his London banker. He may secure discount of the bill at once by cable or await its arrival in London before doing so, or he may request his London banker to have the bill accepted and hold it for maturity. If the bill is discounted the Brazilian banker may draw against it immediately and thus put himself in funds to purchase other coffee bills. Upon receipt of the bill by the London correspondent it is presented to the London banker on whom it is drawn for acceptance. The acceptor bank examines the documents and if they are drawn according to the terms of the credit accepts the draft and returns it to the correspondent of the Brazilian bank, retaining the documents, which it then forwards to the New York bank which opened the credit. In accepting the draft the London bank has in effect agreed to pay it at the end of ninety days, 
or, figuring grace, ninety-three days. Upon maturity payment is made and the amount is charged to the account of the issuing New York bank. Upon receipt of the documents the New York bank delivers them to its customer under a trust receipt or against collateral, and the latter is then in position to obtain the goods. Ten days before the bill of exchange is due in London the New York bank collects the amount from $\mathrm{A}$, together with the commission agreed upon when the credit was opened, and remits the amount to its London banker to meet the draft. On all such transactions the London banker, while not himself advancing any money, is extending a credit for which he charges the New York bank a commission. The result is that we are paying tribute to European bankers amounting to an immense sum annually for the purpose of financing our imports.

The fact that London exchange is more marketable generally throughout the world than New York exchange is one of the principal reasons why it is necessary for us to issue credits upon London instead of upon New York. Another reason lies in the doubtful atthority of American banks to accept time drafts upon themselves.

If our foreign trade should become extended enough to make New York exchange thoroughly marketable in all parts of the world, banking conditions in this country would have to be changed somewhat before we could save the cost of the commissions for acceptance, which we now pay to foreign bankers. We must expect, therefore, to continue to pay Europe commissions for acceptance, as well as freight and insurance in carrying on our foreign trade until our laws are changed. These three items undoubtedly go a long way toward offsetting our favorable trade balance in merchandise.

Our imports are distributed generally throughout the United States. The importers, however, are mostly situated at the ports of entry. A very large proportion of them obtain their credits through New York institutions, although some of them deal direct with foreign bankers. Imports may be stored in bonded warehouses without the payment of duty until such time as the importer desires to obtain the goods for delivery to his customers, provided they are not left to exceed three years. The interest saved on the amount of duty payments thus delayed is quite an item and enables our importers to ship to this country many classes of goods at the low rates that orders in bulk make possible, which they could only 
otherwise import in small quantities and at high prices. While practically all classes of our imports are distributed generally to our people, yet our exports are largely localized. The center of our manufacturing industries lies not far from the center of the State of Ohio. The center of our cotton area is in Mississippi, of our corn area in the western central part of Illinois, of our wheat in Iowa and of our total farms in central Missouri. Our exports are made up of products from these various areas, the centers of which have been continually moving westward and will probably continue to do so for some years yet. Our principal export is cotton, which in recent years has averaged about $\$ 650,000,000$ annually. Other exports are copper, iron and steel, \$250,000,000; meats and dairy products, $\$ 150,000,000$ (a sum which has been decreasing annually for several years) ; corn, wheat and flour, \$125,000,000; oil, \$103,000,000 , and other commodities totaling under $\$ 100,000,000$ but exceeding $\$ 25,000,000$ in about the following order: Lumber, leather (manufactured and unmanufactured), tobacco, coal and coke, cotton manufactures and agricultural implements, all together amounting to seventy-seven per cent of our total exports.

Probably a smaller proportion of our exports is financed by means of commercial letters of credit than of our imports. Different commodities are handled in accordance with special customs which have grown up around them, due partly to trade conditions and partly to the nature of the products. Sellers of grain usually draw at sixty days' sight upon the foreign buyer instead of under a bank credit. These bills, under the customs prevailing in most foreign countries, may be rebated by the foreign buyer whenever he desires to obtain the goods at the "bank rate" or one per cent under the bank rate, or such other rate as custom in the country on which the drafts are drawn requires. Such drafts, with bills of lading and such other documents as are necessary, are purchased by American banks and are forwarded by them to their European correspondents. The American banker is obliged to advance the money on such paper, unless he draws his own time bills against them, until such time as they are rebated. In the case of grain bills the average time rebated is probably around fifty-six days, which places the American bank in possession of demand foreign exchange, against which it can draw in order to reimburse itself with the loss of a very few days' interest. 
Flour bills, which are financed in the same manner as grain bills, usually run nearly to maturity before they are rebated, although the condition of the discount market sometimes influences the purchaser, and causes him to take the bills up more promptly. Many foreign shipments are made under three day sight bills, which uses the money of the American banks making the advance from four to seven days or more, depending upon whether the laws of the country on which the bills are drawn allow grace or not and whether the bills are purchased with intervening days before the sailing of steamers. Other classes of bills are drawn at sight. This includes a portion of our lumber shipments and miscellaneous articles. Where shipments are made on sailing vessels, drafts are frequently drawn at four or six months' sight, and many other transactions go through against cable payments.

As nearly forty per cent of our exports consist of cotton, the method under which it is financed is worthy of special consideration. Cotton bills are ordinarily of two kinds: documentary payment bills and bills drawn upon bankers. Documentary payment bills, which are drawn upon cotton merchants or spinners at sixty or ninety days sight or other tenors, are handled in the same manner as flour bills. The cotton merchant accepts the draft upon presentation and rebates it when the goods arrive, or when he desires to obtain the cotton. A small percentage of cotton is handled in this way. Most of the commodity is financed by means of credits opened by the foreign buyer through his banker. Various abuses have developed under this system, which have caused losses running into millions of dollars to all of the various parties engaged in carrying the transactions to their close. These losses have only been possible because of the turning over of credits by the foreign buyers to irresponsible concerns in America in their endeavor to obtain cotton at lower prices than their competitors. A foreign buyer makes arrangements with certain American concerns to cable him offers of cotton. The American firms whose offers are accepted receive cablegrams from the buyer advising them of the acceptance of their offers and giving them the names of the foreign bankers on whom the drafts in payment of the cotton are to be drawn. The American sellers thereupon ship the cotton to the buyer under bills of lading drawn to the shipper's order and endorsed in blank. The bills of lading are then attached to drafts drawn upon the bankers designated by the buyer 
at the given tenor, which is usually sixty or ninety days. This exchange is then sold in the market to the highest bidder or it is forwarded to New York to be sold in the same manner upon arrival. The American exchange buyers have no means whatever of designating whose bills shall be upon the market, as the sellers are all agents of the European buyers. The American exchange houses in their need for exchange to meet the demands of their importers have accepted the bills offered in the market, each exchange man endeavoring to keep his "water line" on weak names as low as possible. If the European buyers only dealt with first-class houses only first-class bills would be offered, but when they deal with second- or third-rate houses, or houses with no standing whatever, such bills drawn upon prime European banks come upon the market.

The American exchange buyers having the cotton as collateral while the drafts are on the water, and then having the acceptance of a prime European bank for the sixty or ninety days following before maturity of the draft, have accepted these risks, although unwillingly, for want of better bills. They endeavor to protect themselves as far as possible by trying to buy bills only of those in whose honesty they have reason to believe, whether they have any capital back of them or not. If the cotton were actually shipped under a bona fide order, any fluctuation in the value of the cotton which they accepted as collateral, although taken entirely without margin, would probably cause them neither loss nor friction. They have run the risk, however, of having forged documents forced upon them which did not represent goods, or exchange that was drawn without authority. Lines which exchange buyers are willing to take from each cotton shipper before acceptance, and the name of a prime European banker is added to the paper, have to be based upon this consideration.

In the spring of 1910 , forged and fraudulent bills of lading for cotton were attached to drafts that were sold in the foreign exchange market, which resulted ir serious losses to both foreign and domestic buyers and bankers. The foreign bankers thereupon appointed a committee to investigate the matter and to recommend some means under which bankers accepting drafts for cotton could be protected. This committee instead of coming to America met in England, which being so far from the seat of the trouble made it impossible for it to get at all of the facts. The committee arrived at a decision 
not at all in accordance with the requirements nor the possibilities of the case. A resolution was then passed demanding that American exchange buyers guarantee the genuineness of the signature on all bills of lading and the further fact that the goods had actually been delivered to the railroads. In the meantime American bankers and railroad men were holding meetings for the purpose of changing the methods under which bills of lading were issued in such manner as to make fraud more difficult and the risk undertaken by foreign bankers in accepting drafts with cotton bills of lading attached a more reasonable one. A system of validation was agreed upon under which "through order notify" bills of lading are to have validation certificates attached, which proclaim the authority and guarantee the genuineness of the signature of the railroad agent. The validation certificates are to be charged to the agents and audited in the same manner as is done with passenger tickets. They are to be numbered and printed upon a specially protected watermark paper, and are to be attached to the bills of lading in such manner as to make it practically impossible to remove them without detection. These validation certificates will serve a number of purposes and among others will make it possible for those who wish to advance money upon bills of lading to determine with some certainty whether the bills are genuine.

The old form of the cotton bill of lading which has been signed by freight agents or their assistants or others has been an instrument not possible to authenticate. This was particularly dangerous, due to the manner in which bills of lading were issued. They were formerly given out to the shippers, who filled them in and returned them to the railroad agent, who in turn often signed them without having any knowledge as to whether the goods called for by the bill of lading were in his possession or not. Under the new system, no validated bills of lading are to be given up until the goods are actually in possession of the railroads. This system went into effect September I, I9I0, and it is confidently hoped that it will give sufficient added safety to the bills of lading of American railroads to satisfy the foreign bankers.

The very act of guaranteeing such bills is recognized by foreign bankers as being wrong in principle, and while they are requesting that American exchange buyers guarantee bills of lading for exports yet on the other hand they particularly call attention to the fact that 
no bills of lading which pass through their hands for imports to the United States are guaranteed by them in any way, shape or manner. This glaring inconsistency and abrogation of a principle even while it is being stated, can only be attributed to a lack of proper consideration of the subject. There is no doubt, however, but that the whole matter will be adjusted in a manner which will be fair to all concerned. It was quite natural that the tremendous losses incurred through the recent frauds should have at first caused extreme action to have been taken, but it is confidently hoped that our exports of cotton will be handled this coming season without friction or delay. This being the case, the time bills upon foreign bankers will be discounted abroad and the proceeds used to pay for our imports as usual.

The money to finance both our imports and exports is largely furnished by foreign bankers or discount companies. This is of great value to the old countries where capital has accumulated that would otherwise lie idle, and it is of great value to the United States as it enables us to use our own rapidly multiplying capital to develop our country and our industries. In the case of both imports and exports, while the actual capital is largely furnished abroad, our own banking institutions are primarily extending the credits, either through an authorization to foreign bankers to charge drafts drawn under commercial letters of credit to their accounts at maturity in the case of imports, or through the endorsement of bills for exports. Our bankers consequently first feel the necessity for gold shipments, as their inability to meet their obligations with exchange on the one hand or to find a market for their exchange on the other calls for the exportation or importation of gold.

Our imports average about the same amount monthly throughout the year, except during the time of a financial crisis or a change in the tariff. We have then had sudden fluctuations in the imports, which have been very marked. For instance, in 1907 our imports fell off after November from \$I 10,000,000 a month to $\$ 92,000,000$ in December and $\$ 84,000,000$ in January and February of 1908 , and again in the year 1909 great quantities of merchandise were brought in anticipating expected changes in the tariff, which were being considered that year.

The exports, on the other hand, do not go out regularly, but are much larger in the fall and winter months than during the sum- 
mer months. The reason for this lies in the fact that a large proportion of our exports is made up of various crops which ripen in the summer and mature in the fall. A larger amount of exchange, therefore, is made from our merchandise exports after the summer months are over than is required to pay for our imports. Due to various causes, our exports are gradually changing their character and manufactured articles are making up a larger percentage of the total. If it were not for our tremendous exports of cotton, which will undoubtedly continue for the time being in spite of the more or less spasmodic attempts of various foreign countries to grow their own supplies on colonial lands, our exports would soon become as regular as our imports are: as the increase in proportion of manufactured products, which can be produced and shipped equally well at all seasons of the year, has a tendency to equalize monthly shipments. This will have its effect upon foreign exchange rates and cause them to rule more uniformly throughout the year, except at such times as they may be influenced through extraordinary occurrences, such as extreme buying or selling of stocks by foreigners, panics, unusual differences in the value of money in the different countries, etc.

In summary, it may be said that our foreign trade is actually financed largely in London and partly in Paris, Berlin and other European financial centers, but at the risk and upon the credit of American banking institutions. We pay Europe interest and commissions for the use of its money; and, while we have been content to do so in the past, the future will find a shifting of the load on to our own shoulders to a considerable extent. This will come about more and more as our floating capital finds less demand for use in our industries and in the development of our resources. Such a condition will, of course, be greatly retarded by our banking laws, but when the necessity becomes sufficiently great they will be changed to meet the emergency. Then the laws of supply and demand will be allowed free action and will be unhampered by expensive and unnecessary restrictions. In the meantime, while our influence will be great, our actual international, financial force will continue to be comparatively small; but the day will surely come when we shall take our place among the nations of the earth as a real commercial power. 